\title{
GAMBARAN KEJADIAN BODY SHAMING DAN KONSEP DIRI PADA REMAJA DI SMKN 1 KUOK
}

\author{
Alini $^{1}$, Langen Nidhana Meisyalla ${ }^{2}$ \\ Program Studi Sarjana Keperawatan, Universitas Pahlawan Tuanku Tambusai ${ }^{1,2}$ \\ alini_09@yahoo.com ${ }^{1}$,alephswrok@gmail.com ${ }^{2}$
}

\begin{abstract}
Adolescence is a period where there is a change or transition from children to adults that begins at the age of 12 years and will end in the early 20s. Physical condition can be one of the differentiator in teenagers. Physical conditions can make a teenager feel afraid in social relationships. The term body shaming is intended to mock those who have a physical appearance that is considered quite different from society in general.Body shaming is one type of bullying where the individual is seen as a negative side of his physical appearance by others. Body shaming can affect adolescent self-concept. Self-concept is the way an individual sees himself as a whole. In adolescence, self-concept is an important category to reveal about his identity. The purpose of the study was to find out the description of body shaming and selfconcept in students at SMK Negeri 1 Kuok in 2021. The type of research was quantitative research with descriptive analysis design. The study was conducted on July 8, 2021 with a sample of 158 students at SMK Negeri 1 Kuok using a stratified random sampling technique. Data collection using an online questionnaire. Analysis of the data used is univariate analysis. The results of univariate analysis showed that 85 respondents (53.8\%) experienced high body shaming and 89 respondents (56.6\%) had low selfconcept. Respondents are expected to be able to further improve their self-concept by starting to love themselves to stay happy, and for respondents who experience body shaming further increase their potential.
\end{abstract}

Keywords : Body Shaming, Self Concept, Teen

\begin{abstract}
ABSTRAK
Masa remaja merupakan masa dimana terdapat perubahan atau transisi dari anak-anak ke dewasa yang diawali pada usia 12 tahun dan akan berakhir pada awal 20-an tahun. Kondisi fisik bisa menjadi salah satu pembeda pada diri remaja. Kondisi fisik dapat membuat seorang remaja merasa takut dalam hubungan sosialnya. Istilah body shaming ditujukan untuk mengejek mereka yang memiliki penampilan fisik yang dinilai cukup berbeda dengan masyarakat pada umumnya. Body shaming termasuk salah satu jenis perundungan dimana individu lebih dilihat sisi negatif dari penampilan fisiknya oleh orang lain. Body shaming ini bisa mempengaruhi konsep diri remaja. Konsep diri merupakan cara seorang individu memandang dirinya secara utuh. Pada masa remaja konsep diri termasuk kategori penting untuk mengungkapkan tentang jati dirinya. Tujuan penelitian adalah untuk mengetahui gambaran body shaming dan konsep diri pada siswa/i di SMK Negeri 1 Kuok tahun 2021. Jenis penelitian adalah penelitian kuantitatif dengan desain analisis deskriptif. Penelitian dilakukan pada tanggal 08 Juli 2021 dengan jumlah sampel 158 orang siswa/i di SMK Negeri 1 Kuok menggunakan teknik stratified random sampling. Pengumpulan data menggunakan kuesioner online. Analisa data yang digunakan adalah analisa univariat. Hasil analisa univariat diperoleh 85 responden $(53,8 \%)$ mengalami body shaming tinggi dan 89 responden $(56,6 \%)$ memiliki konsep diri rendah. Diharapkan responden untuk dapat lebih meningkatkan konsep dirinya dengan mulai mencintai dirinya agar tetap bahagia, dan bagi responden yang mengalami body shaming lebih meningkatkan potensi yang dimiliki.
\end{abstract}

Kata Kunci : Body Shaming, Konsep Diri, Remaja

\section{PENDAHULUAN}

Masa remaja merupakan masa dimana terdapat perubahan atau transisi dari anakanak ke dewasa yang diawali pada usia 12 tahun dan akan berakhir pada awal 20-an tahun (Papalia dan Olds, dalam Budiargo, 2015). Menurut Rani, dkk (2017), pada masa ini remaja memiliki tugas untuk mencari 
identitas dirinya dari krisis identitas. Remaja pastinya memiliki penilaian tentang apa yang membedakannya dengan orang lain. Kondisi fisik bisa menjadi salah satu pembeda pada diri remaja. Kondisi fisik dapat membuat seorang remaja merasa takut dalam hubungan sosialnya (Damarhadi dkk, 2020). Kelompok remaja kebanyakan mengucilkan remaja lainnya karena ada hal-hal yang berbeda seperti warna kulit, latar belakang, aspek berpakaian, gesture, dan selera (Apriliyanti dkk, 2016).

Lestary dan Liyanovitasari (2020), menyebutkan bahwa banyak perubahan yang terjadi pada masa remaja. Perubahan yang terjadi pada remaja baik secara fisik, psikis, maupun sosial akan mempengaruhi remaja dengan pembentukan konsep dirinya. Selain itu, lingkungan juga menjadi salah satu pengaruh terbesar dalam pembentukan konsep diri karena pada masa ini individu lebih mudah terpengaruh. Masalah remaja dengan lingkungan menunjukkan bahwa banyak remaja yang tidak paham dengan konsep dirinya (Widiarti, 2017).

Konsep diri merupakan segala ide, pikiran, perasaan, kepercayaan, dan pendirian individu yang disadari dan juga mempengaruhi individu saat berhubungan dengan orang lain (Yusuf dkk, 2015). Individu mengenal dirinya melalui orang lain, seperti apa orang lain menilainya, nantinya bisa membentuk konsep diri individu. Hal ini berkaitan dengan bagaimana seseorang melihat dan menilai dirinya sendiri (Rahmat, 2012).

Konsep diri didapatkan melalui pengalaman pribadi, hubungan dengan orang lain, dan interaksi dengan lingkungan (Yusuf dkk, 2015). Selain itu ada beberapa faktor yang bisa mempengaruhi konsep diri seseorang, seperti pola asuh orang tua, pengaruh teman sebaya, penampilan fisik, dan harga diri. Teman sebaya menjadi faktor paling berpengaruh terhadap konsep diri (Saraswatia dkk, 2015).

Menurut Sarwono (2016), teman sebaya bisa menjadi penyebab konsep diri negatif pada remaja. Teman sebaya mempengaruhi pola kepribadian remaja dengan dua cara.
Pertama konsep diri remaja adalah cerminan dari penilaian teman-teman tentang individunya. Kedua, individu tertekan untuk menyesuaikan ideal diri yang di akui kelompok (Sarwono, 2016). Individu yang memiliki konsep diri positif, cenderung akan lebih ceria dan optimis dan menjadikan setiap kejadian sebagai pembelajarannya untuk menjadi lebih baik lagi (Aditya \& Rusmawati, 2018).

Hasil penelitian yang dilakukan sebelumnya tentang konsep diri pada remaja yang pernah merasakan bullying verbal didapatkan bahwa jumlah remaja yang memiliki konsep diri positif dan negatif hampir seimbang, yaitu yang memiliki konsep diri positif sebanyak $51,1 \%$ dan yang memiliki konsep diri negatif sebanyak 48,9\% (Lestari \& Liyanovitasari, 2020). Hal ini sejalan dengan hasil penelitian Fauzia dan Rahmiaji pada tahun 2019 yaitu konsep diri remaja cenderung seimbang antara konsep diri negatif dan konsep diri positif. Namun hasil penelitian Serni, dkk pada tahun 2020 didapatkan bahwa remaja yang mengalami body shaming cenderung memiliki konsep diri negatif.

Adanya kesenjangan dalam pembentukan konsep diri menyebabkan tindakan perundungan terus terjadi yaitu ketika ada seseorang yang memiliki kekuasaan dan seseorang yang terlihat lemah. (Herdyanti \& Margaretha, 2016). Kesenjangan menimbulkan ketidaknyamanan dalam diri individu yaitu ketika gambaran tentang diri yang dicita-citakannya tidak sesuai dengan kenyataan dirinya (Kiling, 2015).

Perasaan tidak diterima oleh orang lain akan membuat konsep diri individu rendah, emosi yang tidak stabil, tidak responsif, dan memiliki pandangan yang buruk dari dunia, sebaliknya ketika individu merasa diterima oleh orang lain maka akan memunculkan perasaan bahagia, konsep diri yang lebih tinggi, stabilitas emosional dan responsiveness, dan pandangan baik dari dunia (Nurliana, 2015). Semakin kuat konsep diri individu maka individu akan tetap bahagia dalam melewati segala hal dalam 
hidupnya walaupun ia mengalami body shaming (Pratama \& Rahmasari, 2020).

Istilah body shaming ditujukan untuk mengejek mereka yang memiliki penampilan fisik yang dinilai cukup berbeda dengan masyarakat pada umumnya. Contoh body shaming adalah penyebutan dengan gendut, pesek, cungkring, dan lain sebagainya yang berkaitan dengan tampilan fisik (Widagdo dalam Fauzia dan Rahmiaji, 2019).

Pada tahun 2015 di Indonesia ada sebanyak 206 jumlah kasus body shaming dan semakin meningkat menjadi sebanyak 966 kasus pada tahun 2018. Pada tahun 2018 polisi bisa menyelesaikan 374 kasus body shaming dari 966 kasus yang ada, sisanya hingga saat ini kasus tersebut belum dapat terselesaikan. KPAI mencatat berdasarkan hasil survey yang dilakukan pada tahun 2019 sebanyak $68 \%$ kasus body shaming dilakukan oleh siswa SMK di Indonesia (Pratama \& Rahmasari, 2020).

Berdasarkan hasil survey ZAP Clinic pada tahun 2020 didapatkan bahwa sekitar $62,2 \%$ responden mengatakan pernah menjadi korban body shaming. Responden yang berusia 13-22 tahun menjadi korban body shaming terbanyak dengan persentase yaitu $67,8 \%$. Hasil survey yang dilakukan Putri, dkk (2018) ditemukan sebanyak $96 \%$ siswa SMA pernah menjadi korban ataupun pelaku body shaming. Sedangkan hasil survey Body Peace Resolution yang dilakukan oleh Yahoo! Health tahun 2016 menunjukkan bahwa sekitar $94 \%$ remaja perempuan mendapat perlakuan body shaming, sedangkan remaja laki-laki hanya sekitar $64 \%$.

Bentuk body shaming yang paling sering didapatkan oleh korban diantaranya yaitu fat shaming, skinny/thin shaming, rambut tubuh dan, warna kulit (Wijaya dkk, 2021). Walaupun orang yang melakukan body shaming mengatakan hanya sebagai candaan saja atau kadang berniat baik agar orang tersebut menjadi lebih baik, tetapi tetap saja body shaming merupakan bentuk perundungan dan bisa mengganggu kejiwaan seseorang, seperti individu yang menyalahkan diri sendiri, benci terhadap tubuhnya, menarik diri dari lingkungan sosial, stress, depresi bahkan menyebabkan kematian (Mutmainnah, 2020).

Sejalan dengan hasil penelitian Fauzia dan Rahmiaji pada tahun 2019 yang mengemukakan bahwa body shaming menimbulkan body shame yaitu pikiran dan perasan negatif (malu, minder, dan tidak puas) tentang fisik, penampilan, citra diri individu karena tidak mampu mencapai standar ideal yang ada. Hal ini akan membuat kepercayaan diri remaja menurun, lebih sensitif serta lebih berhati-hati dalam segala hal, sensitif tentang tubuh dan makanan, menolak ajakan keluar rumah, hingga remaja yang menutup dan membatasi diri (Masithoh, 2020).

Pada tahun 2017, seorang siswi SMA di Kabupaten Kampar melakukan bunuh diri. Perundungan yang dilakukan temantemannya membuat ia mengalami tekanan mental. Salah satu perundungan yang dia dapatkan yaitu perundungan fisik (body shaming). Teman-temannya menyebut dirinya jelek (Jose, 2017) Selain itu, body shaming juga bisa mengakibatkan individu yang mengalaminya melakukan body shaming juga pada dirinya sendiri dan orang lain (Putri dkk, 2018). Pendapat ini sejalan dengan penelitian dari Fauzia dan Rahmiaji (2019) yang menyatakan bahwa beberapa orang yang mengalami body shaming juga melakukan hal yang sama pada orang lain sebagai bentuk pembelaan dirinya. Selain itu juga timbul sikap perlawanan yang memunculkan konsep body positivity atau respon positif terhadap tubuhnya, namun tidak menutup kemungkinan individu kembali merasa takut dan malu pada tubuhnya kemudian melakukan perubahan sebagai upaya pencegahan terjadinya body shaming. Perubahan yang dilakukan ini sebagai upaya untuk mencapai ideal diri bisa seperti remaja yang melakukan diet, olahraga dan sebagainya.

Pada tahun 2020, seorang siswi SMK di Kabupaten Kampar bertengkar dengan siswi lainnya karena body shaming. Siswi tersebut melakukan perlawanan kepada temannya karena tidak terima diejek oleh temannya. Ia 
membalas dengan body shaming juga kepada temannya dan berujung adu fisik.

Berdasarkan survey awal yang penulis lakukan pada tanggal 26 Februari 2021 secara acak kepada sepuluh orang pelajar di SMK N 1 Kuok tentang body shaming yang penulis angkat pada penelitian ini, ditemukan bahwa semua pelajar tersebut pernah menjadi korban dan juga pelaku body shaming. Ini menunjukkan bahwa siapapun tanpa disadari ataupun disadari pernah melakukan dan juga mendapat tindakan body shaming. Lima dari sepuluh orang pelajar pernah mendapatkan perlakuan fat/skinny shaming, tiga orang pelajar diantaranya sering di ejek jelek oleh teman-temannya dan dua orang pelajar lainnya mengaku mendapatkan body shaming karena jerawat mereka. Ketika ditanyakan lebih lanjut, beberapa mengatakan jika ia menjadi malu dengan kondisi tubuhnya. Selain itu, ditemukan juga bahwa tujuh dari sepuluh pelajar tidak mengalami trauma dan juga tidak melakukan perlawanan setelah mendapatkan perlakuan body shaming. Namun, tiga diantara sepuluh pelajar tersebut melakukan perlawanan dengan memarahi atau menegur dan membalas melakukan body shaming juga. Sembilan dari sepuluh pelajar mengatakan jika body shaming merupakan hal yang lumrah. Mereka menganggap tindakan body shaming bukanlah tindakan yang serius, melainkan hanya candaan belaka. Padahal body shaming ini sudah termasuk kedalam jenis tindakan bullying secara verbal.

Penelitian ini bertujuan untuk melihat gambaran kejadian body shaming dan konsep diri pada remaja di SMK Negeri 1 Kuok.

\section{METODE}

Penelitian ini menggunakan pendekatan penelitian kuantitatif non eksperimen dengan

Tabel 1 Distribusi Frekuensi Karakteristik Responden Berdasarkan Jenis Kelamin dan Usia Pada Siswa/i di SMK Negeri 1 Kuok Tahun 2021

\begin{tabular}{cccc}
\hline No & Jenis Kelamin & Frekuensi (f) & Persentase (\%) \\
\hline 1 & Laki-Laki & 89 & 56,3 \\
2 & Perempuan & 69 & 43,7 \\
\hline Jumlah & & $\mathbf{1 5 8}$ & $\mathbf{1 0 0}$ \\
& & & \\
\hline
\end{tabular}

skala sebagai alat ukur. Desain yang digunakan dalam penelitian ini adalah analisis deskriptif, yang bertujuan untuk melihat gambaran fenomena (kesehatan) yang terjadi didalam suatu populasi tertentu.

Penelitian ini dilakukan di SMK Negeri 1 Kuok pada tanggal 08 Juli 2021. Populasi pada penelitian ini adalah seluruh siswa kelas X-XI di SMK Negeri 1 Kuok yang berjumlah 262 orang. Pengambilan sampel menggunakan tehnik stratified random sampling.

Alat pengumpulan data yang digunakan pada penelitian ini adalah kuesioner. Instrumen A, merupakan instrument untuk mendapatkan data demografi, Data yang dimaksud adalah inisial siswa dan siswi, usia, jenis kelamin dan kelas. Instrumen B, merupakan instrument yang dipakai untuk mengukur kejadian body shaming, instrumen yang digunakan dalam penelitian ini adalah instrumen body shaming yang dikembangkan oleh Sari (2020) yang terdiri dari 26 item pernyataan favorable dan unfavorable. Instrumen $\mathrm{C}$, merupakan instrumen yang digunakan untuk mengukur konsep diri pada remaja menggunakan Tennesee Self Concept Scale Second Edition Short Form (TSCS $2^{\text {nd }}$ ) yang dikembangkan oleh Fitts \& Warren pada tahun 1996 dalam bentuk short form dan telah digunakan oleh Mochtan pada tahun 2019 dan unfavorable.

\section{HASIL}

\section{Karateristik Responden}

Karakteristik data responden dalam penelitian ini terdiri dari jenis kelamin, dan usia. Distribusi frekuensi dapat dilihat pada tabel 1 berikut ini: yang terdiri dari 17 item pernyataan favorable 


\begin{tabular}{cccc}
\hline & Usia (tahun) & Frekuensi (f) & Persentase (\%) \\
\hline 1 & 15 & 1 & 0,6 \\
2 & 16 & 42 & 26,6 \\
$\mathbf{3}$ & $\mathbf{1 7}$ & $\mathbf{7 8}$ & $\mathbf{4 9 , 4}$ \\
4 & 18 & 25 & 15,8 \\
5 & 19 & 8 & 5,1 \\
6 & 20 & 4 & 2,5 \\
\hline Jumlah & & $\mathbf{1 5 8}$ & $\mathbf{1 0 0}$ \\
\hline
\end{tabular}

Berdasarkan tabel 1 dapat dilihat bahwa dari 158 responden, sebagian besar responden berjenis kelamin laki-laki yaitu sebanyak 89 orang $(56,3 \%)$ dan sebagian responden berusia 17 tahun yaitu sebanyak 78 orang $(49,4 \%)$.

\section{Analisa Univariat}

Analisa univariat bertujuan untuk menjelaskan atau menggambarkan karakteristik setiap variabel penelitian. Analisis univariat ini hanya menghasilkan distribusi frekuensi dan persentase dari setiap variabel (body shaming dan konsep diri). Adapun hasil analisis univariat disajikan dalam tabel berikut ini:

Tabel 2: Distribusi Frekuensi Body Shaming Pada Siswa/i di SMK Negeri 1 Kuok Tahun 2021

\begin{tabular}{lccc}
\hline No & $\begin{array}{c}\text { Body } \\
\text { Shaming }\end{array}$ & Frekuensi (f) & $\begin{array}{c}\text { Persentase } \\
(\%)\end{array}$ \\
\hline $\mathbf{1}$ & Tinggi & $\mathbf{8 5}$ & $\mathbf{5 3 , 8}$ \\
\hline 2 & Rendah & 73 & 46,2 \\
\hline Jumlah & & $\mathbf{1 5 8}$ & $\mathbf{1 0 0}$ \\
\hline
\end{tabular}

Berdasarkan tabel 2 dapat dilihat bahwa dari 158 responden, sebagian besar responden mengalami body shaming yang tinggi yaitu sebanyak 85 orang $(53,8 \%)$.

Tabel 3:Distribusi Frekuensi Konsep Diri Pada Siswa/i di SMK Negeri 1 Kuok Tahun 2021

\begin{tabular}{cccc}
\hline No & Konsep Diri & Frekuensi (f) & $\begin{array}{c}\text { Persentase } \\
(\boldsymbol{\%})\end{array}$ \\
\hline 1 & Tinggi & 69 & 43,7 \\
\hline $\mathbf{2}$ & Rendah & $\mathbf{8 9}$ & $\mathbf{5 6 , 3}$ \\
\hline & Jumlah & $\mathbf{1 5 8}$ & $\mathbf{1 0 0}$ \\
\hline
\end{tabular}

Berdasarkan tabel 3 dapat dilihat bahwa dari 158 responden, sebagian besar responden memiliki konsep diri yang rendah yaitu sebanyak 89 orang $(56,6 \%)$.

\section{PEMBAHASAN}

Usia

Pada penelitian ini, responden yang dicakup berada dalam rentang usia 15-20 tahun, dengan usia terbanyak adalah 17 tahun sekitar 78 orang $(49,4 \%)$ dan body shaming tertinggi dialami oleh remaja pada usia 17 tahun yaitu sebanyak 41 orang $(52,6 \%)$. Pada rentang usia tersebut, responden tergolong kelompok usia remaja yang sedang mengalami masa peralihan dimana responden tidak bisa dikatakan sebagai anak kecil, namu pertumbuhan fisik dan mentalnya pun belum bisa dianggap dewasa. Wijayanto \& Hidayati (2021) menyebutkan bahwa pada masa ini remaja mengalami storm dan stress, dimana kerap terjadi pergolakan emosi yang labil dengan diiringi pertumbuhan fisik yang pesat serta perkembangan psikis yang sangat rentan terpengaruh oleh lingkungan.

Menurut asumsi peneliti, usia remaja merupakan usia dimana individu mulai berpikir tentang siapa dirinya dan bagaimana orang lain menggambarkan dirinya. Pada masa ini remaja juga mulai memikirkan bentuk tubuhnya dan bagaimana cara mengatasi perubahan yang ada pada tubuhnya dengan melihat bentuk tubuhn orang lain, artis ataupun teman-temannya. Dari sinilah timbul perlakuan body shaming dari melihat bentuk tubuhn temannya ataupun orang lain yang dianggapnya ideal.

\section{Jenis Kelamin}

Gambaran karakteristik responden tentang jenis kelamin pada penelitian ini diketahui bahwa sebagian besar responden berjenis kelamin laki-laki yaitu sebanyak 89 orang $(56,3 \%)$, sedangkan sisanya $69 \quad(43,7 \%)$ 
berjenis kelamin perempuan. Berdasarkan analisis penelitian ditemukan jika laki-laki mengalami body shaming tinggi lebih banyak dibandingkan perempuan yaitu sekitar 51 orang $(57,3 \%)$.

Menurut asumsi peneliti, hal ini disebabkan oleh banyaknya jumlah siswa laki-laki di SMK Negeri 1 Kuok. Ketika mengalami body shaming siswa laki-laki cenderung akan bereaksi membalas dibandingkan perempuan. Menurut Marta (2016) perempuan lebih mudah mengahyati penilaian subjektif dibandingkan laki-laki. Sehingga perempuan lebih memilih untuk diam dan tidak membalas.

\section{Kejadian Body Shaming}

Body Shaming merupakan perilaku seseorang yang menghina suatu bentuk tubuh orang lain yang memiliki bentuk tubuh tidak ideal dan atau tidak seperti bentuk-bentuk tubuh pada umumnya (Mutmainnah, 2020). Berdasarkan hasil penelitian yang telah dilakukan pada 158 orang responden, diperoleh bahwa sebanyak 85 orang $(53,8 \%)$ mengalami body shaming tinggi dan sebanyak 73 responden $(46,2 \%)$ mengalami body shaming yang rendah.

Januarko dan Setiawati (2013) dalam penelitiannya menyebutkan bahwa individu yang lemah, penurut (mudah merasa cemas, kurang percaya diri, mudah dipimpin serta seseorang yang melakukan hal untuk menyenangkan atau meredam kemarahan orang lain) cenderung menjadi korban perundungan. SEJIWA (2008, dalam Rilla, 2018) menyebutkan bahwa ciri-ciri orang yang bisa mengalami perundungan adalah orang yang lemah, sulit bergaul, tidak percaya diri, tidak cantik/tampan, kekurangan fisik, berbeda dengan yang lain, dan lain sebagainya.

Pada masa remaja, perundungan kerap kali terjadi, seperti body shaming (Hasibuan \& Wulandari, 2016). Beberapa faktor yang mempengaruhinya yaitu teman sebaya. Beberapa remaja cenderung melakukan body shaming karena merasa dirinya lebih hebat (Rilla, 2018).
Peneliti berasumsi jika body shaming di SMK Negeri 1 Kuok disebabkan oleh respon yang diberikan yaitu dengan melakukan body shaming kembali kepada orang lain yang melakukan body shaming kepadanya. Hal ini sejalan dengan penelitian dari Fauzia dan Rahmiaji (2019) yang menyatakan bahwa beberapa orang yang mengalami body shaming juga melakukan hal yang sama pada orang lain sebagai bentuk pembelaan dirinya. Perlawanan dengan cara seperti ini merupakan perlawanan secara negatif. Karena tindakan body shaming walaupun dianggap candaan tetap saja masuk dalam kategori perundungan. Perlawanan dari sisi positif bisa dengan cara mengintropeksi diri dan melakukan perubahan-perubahan yang lebih baik lagi.

Responden yang mengalami body shaming di SMK Negeri 1 Kuok ditemukan mengalami rasa malu pada dirinya sendiri. Peneliti juga menemukan jika responden juga merasa tidak percaya diri dengan dirinya dan sering membandingkan tubuhnya dengan orang lain yang menurutnya ideal. Hasil ini sejalan dengan teori dari Damanik (2018) yang menyebutkan bahwa remaja memiliki cara berpikir yang lebih abstrak dan idealistik serta banyak terjadi perubahan tubuh yang terjadi sehingga menimbulkan seseorang melakukan perbandingan tubuhnya dengan orang lain sehingga menimbulkan rasa malu pada dirinya.

Efek dari rasa malu pada individu yaitu individu akan cenderung untuk mengikuti apa yang orang lain katakan terkait kondisi tubuhnya sehingga menimbulkan rasa tidak percaya diri, tidak menarik dan tidak layak dalam kelompok sosial. Selain itu juga berdampak pada pola pikir seseorang. Body shaming menimbulkan penilaian yang buruk pada diri sendiri (Hidayat dkk, 2019).

Menurut asumsi peneliti, individu yang mengalami body shaming lebih banyak mengarah kepada hal yang buruk. Body shaming merupakan pengalaman individu dimana ia merasa apa yang dilakukannya tidak sesuai dengan apa yang diharapkan diri sendiri dan lingkungan. Hal ini menyebabkan rasa tiak percaya diri, rasa malu, 
ketidakpuasan pada tubuhnya. Walaupun demikian, body shaming juga bisa menyebabkan seseorang ingin memperbaiki dirinya.

\section{Konsep Diri}

Konsep diri adalah kesadaran individu akan identitasnya sendiri. Berdasarkan hasil penelitian, konsep diri responden cenderung seimbang antara konsep diri rendah yaitu 89 orang $(56,3 \%)$ dan konsep diri tinggi yaitu sebanyak 69 responden $(43,7 \%)$.

Konsep diri didapatkan dari lingkungan dan akan menimbulkan persepsi bagi individu tentang dirinya. Konsep diri merupakan segala pemikiran individu tentang aspek pada dirinya yang meliputi aspek fisik, aspek sosial, dan aspek psikologis yang didasarkan oleh bagaimana pengalaman dan interaksi seseorang dengan orang lain. (Nubli dkk, 2018).

Konsep diri dapat dilihat dari tingkah laku yang muncul dan berkembang pada diri seseorang melalui pengalaman dan interaksinya dengan lingkungannya sehingga dapat membentuk konsep diri yang positif atau konsep diri yang negatif. Konsep diri yang positif akan mampu mengenali dan menerima dirinya apa adanya, cenderung memiliki sifat rendah hati dan memiliki harapan yang realistis serta harga diri yang tinggi. Begitupun sebaliknya, orang yang memiliki konsep diri negatif cenderung memiliki sifat tinggi hati dan tidak percaya diri (Afriyanto \& Muzdalifah, 2014).

Menurut asumsi peneliti, rendahnya konsep diri pada remaja disebabkan oleh lingkungannya seperti teman sebaya dan juga keluarga. Hal ini sesuai dengan pendapat Nubli, dkk (2018) yang menyebutkan jika konsep diri pada remaja dipengaruhi oleh banyak hal, diantaranya adalah penampilak fisik, lingkungan keluarga dan juga teman sebaya.

\section{KESIMPULAN}

Berdasarkan hasil penelitian diketahui bahwa 85 responden $(53,8 \%)$ mengalami body shaming tinggi dan 89 responden
(56,6\%) memiliki konsep diri rendah. Diharapkan responden untuk dapat lebih meningkatkan konsep dirinya dengan mulai mencintai dirinya agar tetap bahagia, dan bagi responden yang mengalami body shaming lebih meningkatkan potensi yang dimiliki

\section{UCAPAN TERIMA KASIH}

Ucapan terima kasih disampaikan kepada seluruh responden penelitian, Rektor, Wakil Rektor, Dekan FIK, serta Ketua LPPM Universitas Pahlawan Tuanku Tambusai.

\section{DAFTAR PUSTAKA}

Aditya, V., \& Rusmawati, D. (2018). Hubungan Antara Konsep Diri dengan Intensi Bullying pada Siswa SMA $N 1$ Purbalingga. Jurnal Empati, 7 (3), 252-258. Jawa Tengah, Universitas Diponegoro. https://ejournal3.undip. ac.id/index.php/empati/article/view/21 85.Diperoleh pada tanggal 05 Maret 2021.

Afriyanto, B. H., \& Muzdalifah, F. (2014). Pengaruh Konsep Diri Terhadap Perilaku Bullying Pada Mahasiswa di Universitas $X$. Jurnal Penelitian dan Pengukuran Psikologi, 59-64. http://journal.unj.ac.id/unj/index.php/j ppp/ article/view/5528. Diperoleh pada tanggal 12 Juli 2021

Apriliyanti, A., Mudjiran, \& Ridha, M. (2016). Hubungan Konsep Diri Siswa Dengan Tingkah Laku Sosial Siswa. Jurnal Education : Jurnal Pendidikan Indonesia, 2(2), 25-29. Universitas Negeri Padang. https://jurnal.iicet.org/ index.php/j-edu/article/view/62.

Diperoleh pada tanggal 05 Maret 2021.

Budiargo, Dian. (2015). Berkomunikasi Ala Net Generation. Jakarta : PT Elex Media Komputindo

Damanik, T. M. (2018). Dinamika Psikologis Remaja Perempuan Mengalami Body Shame. Yogyakarta: Universitas Sanata Dharma. 
https://repository.usd.ac.id/30840/.

Diperoleh tanggal 12 Juli 2021

Damarhadi, S., Mujidin, \& Prabawanti, C. (n.d.). Gambaran Konsep Diri Pada Siswa SMA Ditinjau Berdasarkan Jenis Kelamin. Psikostudia: Jurnal Psikologi, 9 (3), 251-259. Yogyakarta, Fakultas Psikologi Universitas Mulawarman. http://ejournals.unmul.ac.id/index.php/PSIK O/article/view/ 4392. Diperoleh pada tanggal 27 Februari 2021.

Donsu, J. D. (2016). Metodologi Penelitian Keperawatan. Yogyakarta: Pustaka Baru Press.

Fauzia, T. F., \& Rahmiaji, L. R. (2019). Memahami Pengalaman Body Shaming pada Remaja. Jurnal Ilmu Sosial dan Ilmu Politik. Semarang: Universitas Diponegoro. https://ejournal3.undip.ac.id/index.php /interaksi-online/ article/view/24148. Diperoleh pada tanggal 22 Februari 2021.

Hadi, F. D., \& Rusmawati, D. (2019). Hubungan antara Keharmonisan Keluarga dengan Konsep Diri pada Siswa Kelas XI SMA Negeri 1 Demak. Jurnal Empati, 26-32. https://ejournal3.undip.ac.id/index.php /empati/article/view/ 24399. Diperoleh pada tanggal 13 Juli 2021

Hasibuan, R. L., \& Wulandari, L. H. (2015). Efektivitas Rational Emotive Behavior Therapy (REBT) untuk Meningkatkan Self Esteem pada Siswa SMP Korban Bullying. Jurnal Psikologi, 103-110. http://ejournal.uin-

suska.ac.id/index.php/psikologi/article /view/1559. Diperoleh pada tanggal 22 Februari 2021.

Herdyanti, F., \& Margaretha. (2016). Hubungan Antara Konsep Diri dengan Kecendrungan Menjadi Korban Bullying pada Remaja Awal. Jurnal Psikologi Undip, 15 (2), 92-98. Surabaya, Fakultas Psikologi Universitas Airlangga. https://ejournal.undip.ac.id/index.php/ psikologi/article/view/ 12645/pdf.
Diperoleh pada tanggal 05 Maret 2021.

Hidayat, R., Malfasari, E., \& Herniyanti, R. (2019). Hubungan Perlakuan Body Shaming Dengan Citra Diri Mahasiswa. Jurnal Keperawatan Jiwa, 7 (1), 79-86. Sekolah Tinggi Ilmu Kesehatan Payung Negeri Pekanbaru. https://jurnal.unimus.ac.id/ index.php/JKJ/article/view/4770. Diperoleh pada tanggal 10 Februari 2021

Januarko, W., \& Setiawati, D. (2013). Studi Tentang penanganan Korban Bullying pada Siswa SMP Se-Kecamatan Trawas. Jurnal BK UNESA, 383-389. https://jurnalmahasiswa.unesa.ac.id/in dex.php/jurnal-bk-unesa/ article/view/7440. Diperoleh pada tanggal 12 Juli 2021

Jose, S. (2017, Agustus 2). Siswa SMAN 1 Bangkinang yang Akhiri Hidup dengan Bunuh Diri diduga Sering Diejek Jelek dan Miskin. Berita GoRiau.

https://m.goriau.com/berita/baca/siswi -sma-1-bangkinang-yang-akhirihidup-dengan-bunuh-diri-didugasering-diejek-jelek-dan-miskin.html. Diperoleh pada tanggal 22 Februari 2021.

Kiling, B. N., \& Kiling, I. Y. (2015). Tinjauan Konsep Diri Dan Dimensinya Pada Anak Dalam Masa Kanak-Kanak Akhir. Jurnal Psikologi Pendidikan \& Konseling, 1(2), 116124.

https://ojs.unm.ac.id/index.php/JPPK/ article/ view/1811. Diperoleh pada tanggal 05 Maret 2021.

Lestari, P., \& Liyanovitasari. (n.d.). Konsep Diri Remaja Yang Mengalami Bullying. Jurnal Keperawatan Terpadu, 2 (1), 40-46. http://jkt.poltekkesmataram.ac.id/index.php/home/article/ view/45. Diperoleh pada tanggal 14 Februari 2021.

Marta, J. (2016). Eating Behaviors Exploring the Effect of External Shame on Body 
Appreciation among Portuguese young adults: The Role of selfcompassion. . Eating Behaviors. 174179. https://pubmed.ncbi.nlm.nih. gov/27816855/. Diperoleh pada tanggal 12 Juli 2021.

Masithoh, N. A. (2020). Body Shame pada Mahasiswa Generasi Milenial Di Universitas Negeri Semarang. Skripsi. Universitas Negeri Semarang. http://lib.unnes.ac.id/42229/1/151141 4042_Nurul\%20Aida\%20Masithoh_P sikologi.pdf. Diperoleh pada tanggal 17 Februari 2021.

Mutmainnah, A. N. (2020, Februari). Analisis Yuridis Terhadap Pelaku Penghinaan Citra Tubuh (Body Shaming) Dalam Hukum Pidana di Indonesia. Dinamika, Jurnal Ilmiah Ilmu Hukum, 26 (8), 975-987. Universitas Islam Malang.

http://www.riset.unisma.ac.id/index.p $\mathrm{hp} / \mathrm{jdh} /$ article/view/5864. Diperoleh pada tanggal 21 Februari 2021.

Notoatmodjo, S. (2015). Metodologi Penelitian Kesehatan. Jakarta: PT Rineka Cipta

Nubli, M. H., Marni, E., \& Anggreny, Y. (2018). Hubungan Konsep Diri pada Remaja Terhadap Kemampuan Menghadapi Perilaku Bullying di SMKN 2 Pekanbaru. Jurnal Ners Indonesia, 51-58. https://jni.ejournal.unri.ac.id/index.ph $\mathrm{p} / \mathrm{JNI} / \mathrm{article/view/7594}$. Diperoleh pada tanggal 12 Juli 2021.

Nurliana, Y. (2015). Konsep Diri Remaja (Siswa Kelas X SMA). Psikologi dan Kemanusiaan, 440-445. Universitas Muhammadiyah Malang. https://mpsi. umm.ac.id/files/file/441 -

445\%20Yetti\%20Nurliana.pdf.

Diperoleh pada tanggal 21 Februari 2021.

Pratama, A. S., \& Rahmasari, D. (2020). Hubungan antara Body Shaming dan Happiness dengan Konsep diri sebagai Variabel Mediator. Jurnal Penelitian Psikologi, 7 (3), 85-94. Universitas Negeri Surabaya. https://jurnalmahasiswa.unesa.ac.id/in dex.php/character/article/view/35105\# : :text=Hasil\%20penelitian\%20menu njukkan\%20bahwa\%20body,antara\% 20body\%20shaming\%20dan\%20Happ iness. Diperoleh pada tanggal 13 Maret 2021.

Putri, B. A., Pranayama, A., \& Sutanto, R. P. (2018). Perancangan Kampanye “ Sizter 's Project " sebagai Upaya Pencegahan Body Shaming. Journal DKV, 1, 1-9. Surabaya, Universitas Kristen Petra. http://publication.petra. ac.id/index.php/dkv/article/view/7275. Diperoleh pada tanggal 05 Maret 2021.

Rakhmat, J. (2011). Psikologi Komunikasi. Bandung: PT. Remaja Rosda Karya.

Rilla, E. V. (2018). Hubungan Bullying dengan Konsep Diri Remaja di SMP Negeri 5 Garut Tahun 2017. Health Sciences Journal, 116-124. https://ejournal.stikku.ac.id/index.php/ stikku/article/view/70. Diperoleh pada tanggal 12 Juli 2021

Saraswatia, G. K., Zulpahiyana, \& Arifah, S. (2015). Faktor-Faktor yang Mempengaruhi Konsep Diri Remaja. Jurnal Ners dan Kebidanan Indonesia, 3 (1), 33-38. Yogyakarta, Sekolah Tinggi Ilmu Kesehatan Alma Ata Yogyakarta.

https://ejournal.almaata.ac.id/index.ph p/JNKI/article/ view/97. Diperoleh pada tanggal 05 Maret 2021.

Wijaya , A., Kebayantini, N. L., \& Aditya, I. G. (2021). Body Shaming Dan Perubahan Perilaku Sosial Korban (Studi Pada Remaja Di Kota Denpasar). Jurnal Ilmiah Sosiologi (Sorot). Universitas Udayana. https://ojs.unud.ac.

id/index.php/sorot/article/view/69033. Diperoleh pada tanggal 21 Februari 2021.

Wijayanto, G. A., \& Hidayati, E. (2021). Konsep Diri Pada Remaja yang mengalami Bullying. Jurnal Keperawatan Silampari, 503-509. https://journal.ipm2kpe.or.id/index.ph 
p/JKS/article/view/1947. Diperoleh pada tanggal 12 Juli 2021

Yusuf, A., K, R. F., \& Nihayati, H. E. (2015). Buku Ajar Keperawatan Kesehatan Jiwa. Jakarta: Salemba Medika. 